\title{
SARANA KREATIFITAS, REKREASI, DAN KOMUNITAS DI KAWASAN RS FATMAWATI,
} JAKARTA SELATAN

\author{
Ivana Widjaja ${ }^{1),}$ Diah Anggraini ${ }^{2)}$ \\ 1) Program Studi S1 Arsitektur, Fakultas Teknik, Universitas Tarumanagara, veronicaivannaa@gmail.com \\ 2) Program Studi S1 Arsitektur, Fakultas Teknik, Universitas Tarumanagara, diaha@untar.ac.id
}

Masuk: 10-01-2020, revisi: 28-01-2020, diterima untuk diterbitkan: 09-05-2020 (doi: 10.24912/stupa.v2i1.6867)

\begin{abstract}
Abstrak
Jam kerja yang sangat padat dan tugas-tugas pekerjaan yang banyak dapat menyebabkan adanya beban pikiran dan stress. Oleh karena itu, setiap individu pasti membutuhkan tempat yang dapat membantunya melepaskan diri dari stres dan lelah. Dalam rangka memenuhi kebutuhan tersebut, maka sebuah ruang publik yang bersifat menghibur sangat dibutuhkan keberadaanya dalam rangka memenuhi kebutuhan manusia. Kajian ini bertujuan menghasilkan konsep perancangan suatu $3 r d$ place yang dapat menaungi berbagai aktifitas sebagaimana tersebut di atas. Dalam menyusun konsep perancangan ini, akan mengaju pada metode observasi, sementara pemahaman terhadap lokasi baik fisik maupun kondisi sosial budaya masyarakat, akan digunakan riset kualitatif deskriptif. Kajian ini menghasilkan konsep perancangan dan perancangan suatu 3rd place di kawasan Fatmawati Jakarta Selatan.
\end{abstract}

Kata kunci: kreatifitas; rekreasi; komunitas; Fatmawati

\begin{abstract}
Very tight working hours and a lot of work assignments can cause high level of stress. Therefore, every individual need a place that can help them escape from stress and fatigue. In order to meet these needs, an entertaining public space is very much needed in order to meet human needs. This study aims to produce a 3rd place design concept that can overshadow a variety of activities as mentioned above. In compiling this design concept, it will refer to the method of observation, while understanding the location of both the physical and socio-cultural conditions of the community, descriptive qualitative research will be used. This study resulted in the design concept and design of a 3rd place in the Fatmawati area of South Jakarta.
\end{abstract}

Keywords: creativity; recreation; community; Fatmawati

\section{PENDAHULUAN}

\section{Latar belakang}

Jam kerja yang sangat padat dan pekerjaan yang banyak dapat menyebabkan adanya beban pikiran dan stres. Oleh karena itu, setiap individu pasti membutuhkan tempat yang dapat membantu melepaskan diri dari stress dan lelah. Di zaman modern yang serba cepat dan serba canggih menjadikan manusia menjadi makhluk individual, padahal pada hakekatnya manusia merupakan mahluk social yang membutuhkan interaksi satu sama lain.

Sebuah ruang publik yang bersifat menghibur sangat dibutuhkan keberadaanya dalam rangka memenuhi kebutuhan manusia. Dalam masyarakat zaman moderen ini kebutuhan akan adanya ruang publik merupakan kebutuhan yang penting.

Adanya ruang publik ini diharapkan dapat menciptakan adanya interaksi, percakapan antar individu, sebagai cerminan hakat manusia sebagai mahkluk sosial. Percakapan- percakapan dan interaksi kecil yang terbentuk pada tempat ini juga dapat menjadikan sebuah tempat pelepas stress pada masyarakat, oleh karena itu sangat penting disediakan fasilitas- fasilitas yang dapat mendukung berbagai aktivitas. 
Seperti yang dapat kita lihat di daerah Cilandak, daerah yang didominasi dengan perumahan dan permukiman gedung-gedung perkantoran dan tempat-tempat kerja lainnya, maka menjadikan wilayah ini membutuhkan fasilitas-fasilitas hiburan yang dapat melepas lelah, kejenuhan dan stres.

\section{Rumusan masalah}

a. Bagaimana menciptakan fasilitas $3^{\text {rd }}$ place yang dapat mewadahi interaksi sosial yang terbuka bagi seluruh kalangan masyarakat dan mengurangi tingkat kesenjangan sosial?

b. Bagaimana agar $3^{\text {rd }}$ place yang tercipta dapat menjadi wadah yang memenuhi kriteria open architecture

\section{Pembatasan Masalah}

Berdasarkan tujuan perancangan dalam mengatasi kesenjangan sosial, maka proyek difokuskan pada kebutuhan akan $3^{\text {rd }}$ place di kawasan sekitarr RS Fatmawati, tidak hanya itu proyek ini juga difokuskan kepada Sustainable development goals sebagai solusi bagi generasi millennial. Pembatasan kawasan pengamatan dibatasi dengan berfokus pada Kecamatan Cilandak, Jakarta Selatan.

\section{Tujuan kajian}

Tujuan kajian ini adalah menghasilkan konsep perancangan proyek "Sarana Kreatifitas, Rekreasi, dan Komunitas di sekitar RS Fatmawati" dituliskan dalam bentuk visi dan misi, visi yang diharapkan perancang dalam merancang proyek ini antara lain :

a. menciptakan fasilitas $3^{\text {rd }}$ place yang dapat mewadahi interaksi sosial yang terbuka bagi seluruh kalangan masyarakat dan mengurangi tingkat kesenjangan sosial

b. merancang $3^{\text {rd }}$ place yang dapat menjadi wadah yang memenuhi kriteria open architecture

Dalam rangka merealisasikan visi tersebut di atas, maka perancang memiliki misi antara lain :

- Membuat tempat ketiga yang menawarkan berbagai fasilitas edukasi non- formal dan workshop kepada penggunanya.

- Membuat tempat ketiga yang dapat menciptakan adanya interaksi sosial antar pengujung.

- Menjadikan rancangan ini sebagai sebuah sarana yang dapat menjadi titik bertemunya masyarakat yang dapat menjadi wadah untuk membagikan pembelajaran bagi sesamanya.

\section{KAJIAN LITERATUR}

Ada beberapa teori yang digunakan dalam perancangan serta pengusungan proyek, diantaranya sebagai berikut:

\section{Third place ${ }^{1}$}

Dalam pembangunan komunitas, tempat ketiga adalah lingkungan sosial yang terpisah dari dua lingkungan sosial rumah yang biasa ("tempat pertama") dan tempat kerja ("tempat kedua"). Contoh tempat ketiga adalah lingkungan seperti gereja, kafe, klub, perpustakaan umum, atau taman. Dalam bukunya yang berpengaruh, The Great Good Place, Ray Oldenburg $(1989,1991)^{1}$ mengemukakan bahwa tempat ketiga penting bagi masyarakat sipil, demokrasi, keterlibatan sipil, dan membangun perasaan rasa tempat.

\footnotetext{
${ }^{1}$ Oldenburg, Ray. 1989, 1991. The Great Good Place
} 
Transit Oriented Development : City Of Austin ${ }^{2}$

Prinsip-prinsip berikut berfungsi sebagai panduan dan memberikan pemahaman tentang elemen-elemen penting dan karakteristik TOD, antara lain :

- Membuat perancangan di daerah yang jaraknya mudah dicapai dengan angkutan umum dan di daerah yang jumlah penduduknya mendukung adanya transportasiumum

- Membuat para pejalan kaki fokus kepada strategi pengembangan tanpa mengecualikan kendaraan.

- Menciptakan tempat-tempat aktif dan komunitas yang layak huni yang melayani kebutuhan sehari-hari dan di mana orang merasakan rasa memiliki dan kepemilikan.

- Termasuk ruang publik yang menarik dan berkualitas tinggi (mis. Taman atau plaza kecil) sebagai fitur pengorganisasian dan tempat berkumpul untuk lingkungan.

- Mendorong berbagai jenis perumahan di dekat fasilitas transit yang tersedia untuk berbagai usia dan pendapatan.

- Memasukkan komersial yang menarik pelanggan baik dari TOD dan jalan utama.

- Pastikan kompatibilitas dan konektivitas dengan lingkungan sekitar.

- Memperkenalkan strategi parkir kreatif yang terintegrasi, dari pada membagi tapak dan mengurangi kesenjangan sosial.

- Buat rencana TOD yang fleksibel sehingga mereka dapat menanggapi perubahan kondisi.

\section{Commercial}

Komersial adalah sesuatu yang memungkinkan seseorang untuk menarik keuntungan dari produk si pencipta. Komersial juga dapat diartikan sebagai sesuatu hal yang terkait dengan pembelian dan penjualan barang atau jasa, yang mencakup semua kegiatan dan hubungan industri perdagangan.

\section{Personal Space (Alt man, 1975)}

Menurut Sommer ruang personal adalah daerah di sekeliling seseorang dengan batasanbatasan yang tidak jelas dimana orang lain tidak boleh memasukinya. Goffman menggambarkan ruang personal sebagai jarak / daerah di sekitar individu dimana dengan memasuki daerah orang lain, menyebabkan orang tersebut merasa batasnya dilanggar, merasa tidak senang, dan kadangkadang dapat menarik diri.

\section{Open Architecture ${ }^{5}$}

Open Architecture merupakan sebuah konsep dimana arsitektur terbuka bagi segala masukan, seperti perkembangan budaya, perubahan zaman, perkembangan teknologi, dan perubahan manusia. Konsep ini menjadikan arsitektur sebuah desain yang tidak kaku, tetapi sebuah desain yang mengikuti arus perkembangan zaman.

\footnotetext{
${ }^{2}$ City Of Austin. Transit Oriented Development. Austin di http://www.austintexas.gov/department/transit-oriented-development

${ }^{3}$ Hamilton, Roger. 2003. di https://www.pengertianmenurutparaahli.net/pengertian-

komersial-dan-nonkomersial/

${ }^{4}$ Goffman. 1975. Alt man di http://novenadwirespita10508159.blogspot.com/2011/02/personal- space.html

${ }^{5}$ Winata, S. (2019), The Third place. Materi Kuliah Stupa 8 Prodi SS1 Arsitektur UNTAR. Jakarta
} 
Sustainable Development goals ${ }^{6}$

Tujuan Pembangunan Berkelanjutan (SDGs) adalah kumpulan 17 tujuan global yang dirancang untuk menjadi "cetak biru untuk mencapai masa depan yang lebih baik dan lebih berkelanjutan untuk semua". SDGs, ditetapkan pada tahun 2015 oleh Majelis Umum PBB dan dimaksudkan untuk dicapai pada tahun 2030, merupakan bagian dari Resolusi PBB 70/1, Agenda 2030.

Tujuan Pembangunan Berkelanjutan adalah: Tanpa Kemiskinan

- Nol Kelaparan

- Kesehatan dan Kesejahteraan yang baik

- Kualitas pendidikan

- Kesetaraan gender

- Air Bersih dan Sanitasi

- Energi yang Terjangkau dan Bersih

- Pekerjaan yang Layak dan Pertumbuhan Ekonomi

- Industri, Inovasi, dan Infrastruktur

- Mengurangi Ketimpangan

- Kota dan Komunitas Berkelanjutan

- Konsumsi dan Produksi yang Bertanggung Jawab

- Aksi Iklim

- Kehidupan di Bawah Air

- Kehidupan di Darat

- Perdamaian, Keadilan, dan Lembaga Kuat

- Kemitraan untuk Tujuan

\section{METODE}

Metode yang digunakan penulis dalam makalah ini adalah model pendekatan riset dengan metode deskriptif. Pengumpulan data dilakukan dengan beberapa cara, yaitu:

\section{a. Kajian teoritis}

Penelitian ini juga menggunakan berbagai teori yang relevan dengan konteks permasalahan dan menganalisa penelitian-penelitian terdahulu yang sejenis. Kajian teoritis dilakukan dengan cara membaca, menganalisa, meringkas, dan mengutip.

\section{b. Observasi}

Obeservasi dilakukan untuk mengetahui secara langsung kondisi fisik dan kondisi sosial kawasan pengamatan terpilih. Teknik ini dilakukan dengan beberapa kegiatan di antaranya pengamatan kondisi fisik dan sosial, pemetaan, pencatatan dan dokumentasi pribadi.

\section{c. Data Sekunder}

Penelitian ini juga melakukan pengamatan terhadap data statistik kawasan pengamatan terbaru untuk mengetahui data kuantitatif kawasan demi keakuratan penelitian.

\section{d. Metode Desain}

Metode desain yang digunakan adalah metode metaphor / metafora. Metode desin ini merupakan metode yang meniru betuk dari suatu benda/objek. Bentuk benda/ objek ini mnejadi sebuah inspirasi yang nantinya akan di aplikasikan kedalam bentuk bangunan baik secara mentah, maupun dengan olahan.

Seperti perancangan $3^{\text {rd }}$ place kali ini, bentuk bangunan di tiru dari bentuk sekumpulan orang yang saling memeluk. Orang-orang yang memeluk ini juga melambangkan $3^{\text {rd }}$ place yang dibangun merupakan $3^{\text {rd }}$ place yang terbuka baig semua orang.

\footnotetext{
${ }^{6}$ dpicampaigns. "About the Sustainable Development Goals". United Nations Sustainable Development. Retrieved 9 November2019
} 


\section{DISKUSI DAN HASIL}

\section{Data Proyek}

Judul proyek : Sarana Kreatifitas, Rekreasi, dan Komunitas di Kawasan Rs Fatmawati, Jakarta Selatan.

Lokasi proyek : Jl. Fatmawati, Cilandak, Jakarta Selatan.

Luas tapak perancangan : 7094,4 $\mathrm{m} 2$

Luas lantai dasar : 1721,28 m2, yang berarti 24,26\%, angka tersebut masih dibawah batas maksimal KDB yang ditentukan.

Luas keseluruhan lantai : 5737,6 m2, yang berarti 0.8 kali dari luasan tapak, angka tersebut masih dibawah batas maksimal KLB yang ditentukan.

Ketinggian bangunan : Bangunan memiliki ketinggian 4 lantai, angka tersebut masih memenuhi batas ketinggian bangunan yang telah diterapkan oleh pemerintah.

\section{Konsep Perancangan}

Bentuk bangunan yang melengkung yang melambangkan seperti memeluk, dimana berati bangunan memeluk semua orang, terbuka bagi siapa saja, dari kalangan manapun, segala usia, segala jenis kelamin. Bangunan terinspirasi dari bentuk orang yang saling memeluk dan sekelompok orang yang saling berpeggangan tangan. Bangunan juga mengusut bentuk dari pertimbangan segala jenis aturan pembangunan dan segaka jenis kebutuhan baik kebutuhan masyarakat sekitar, maupun kebutuhan lingkungan sekitar.

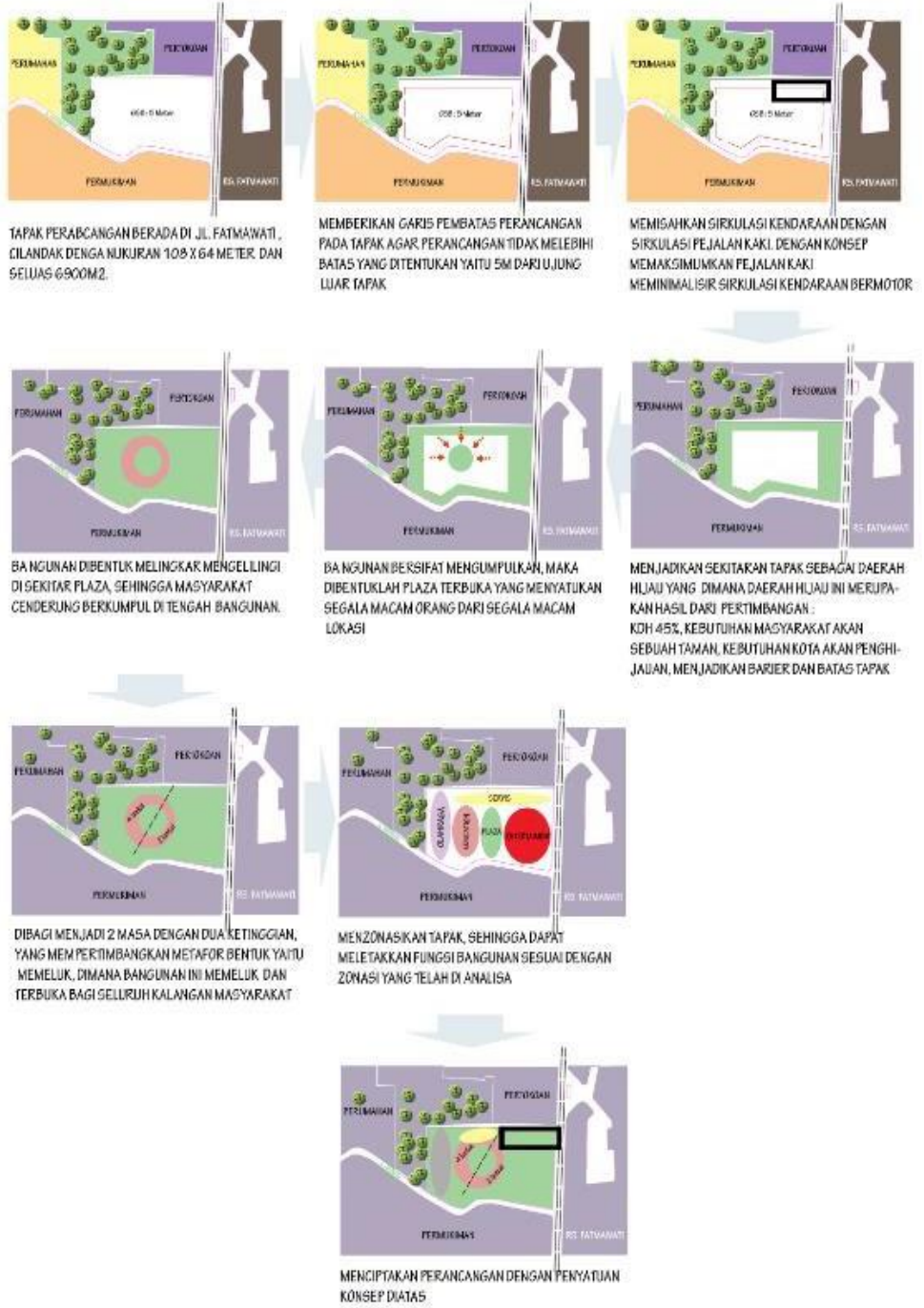

Gambar 1. Proses pembentukan massa

Sumber: Penulis, 2019 


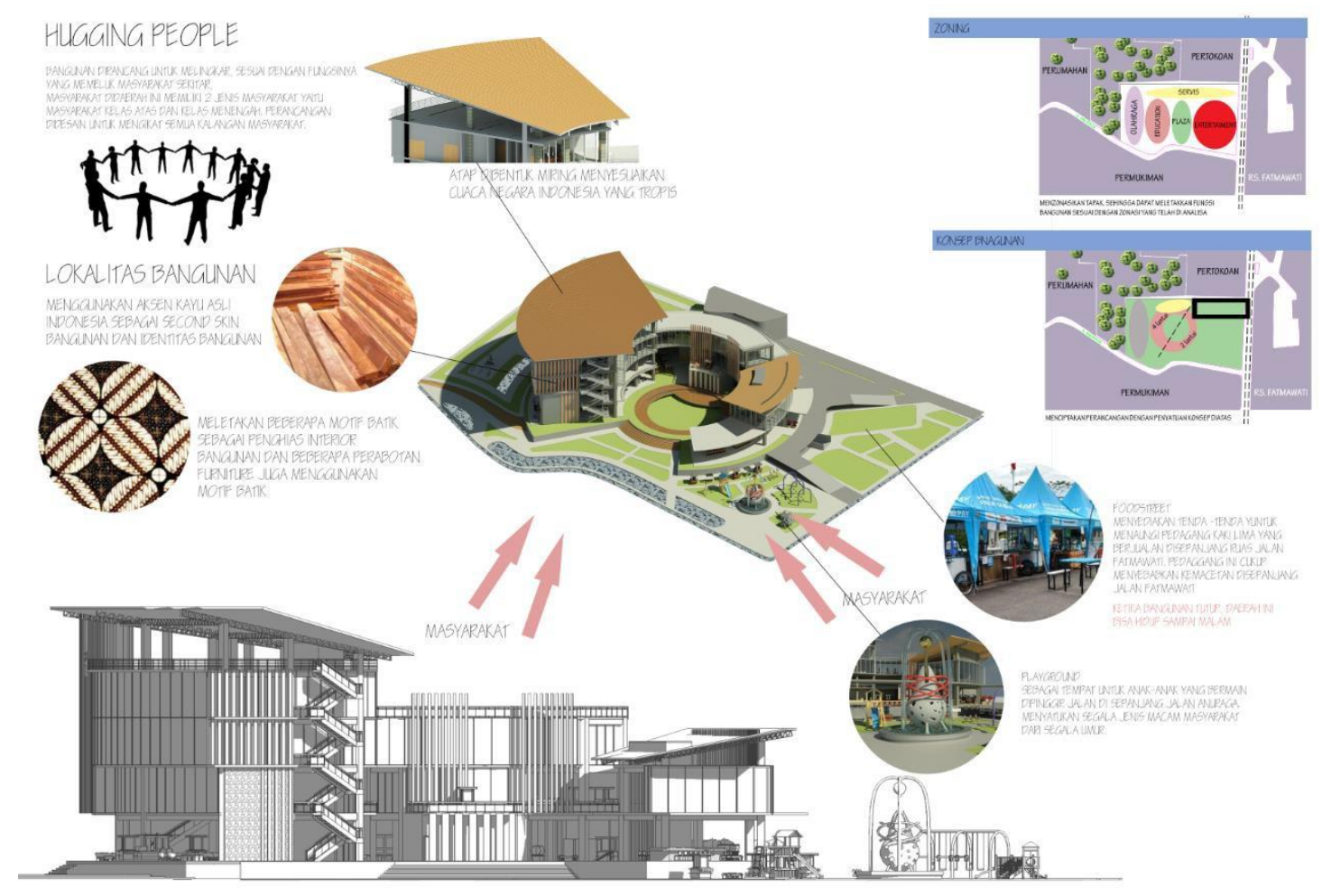

Gambar 2. Konsep bangunan

Sumber: Penulis, 2019

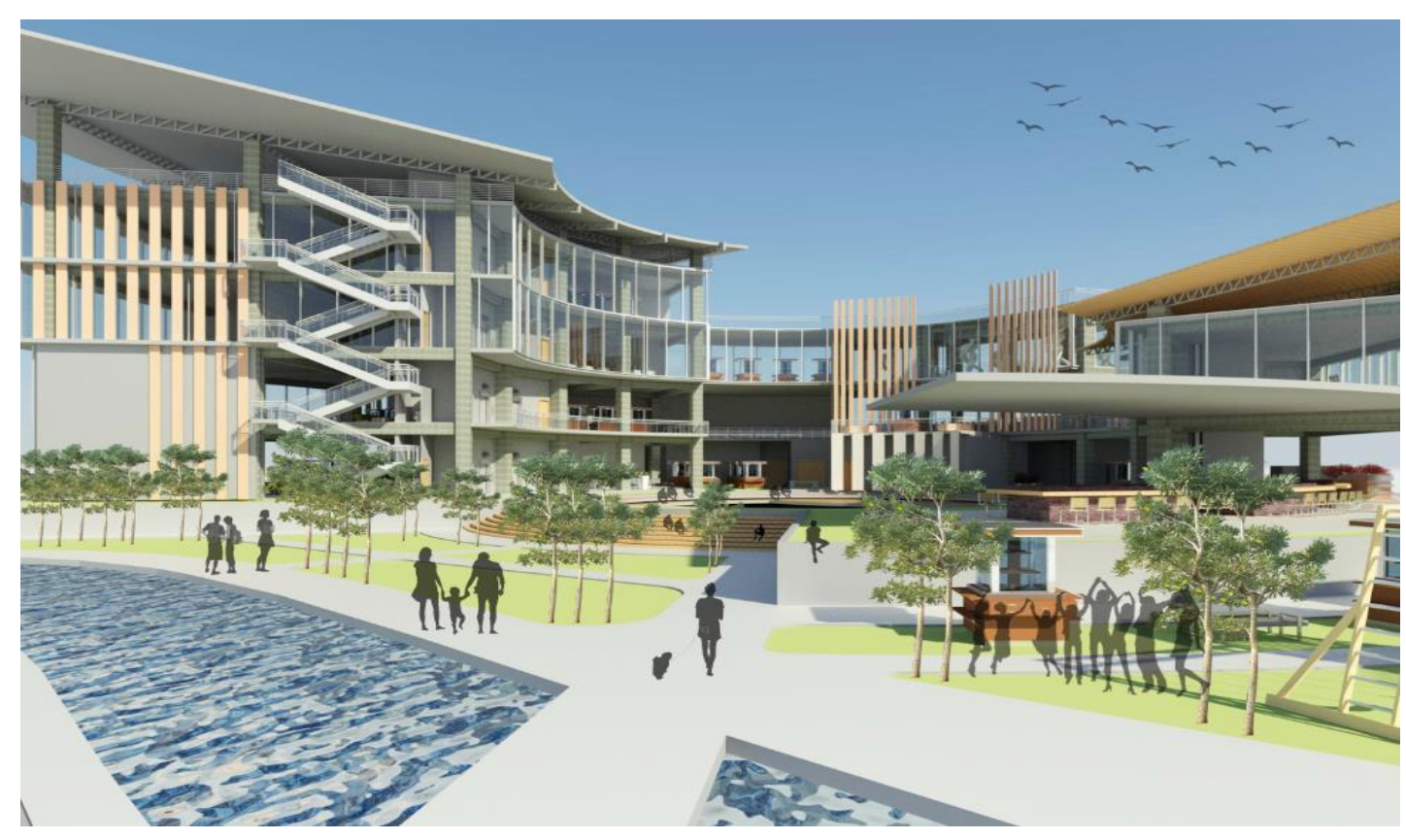

Gambar 3. Prespektif Eksterior

Sumber: Penulis, 2019 


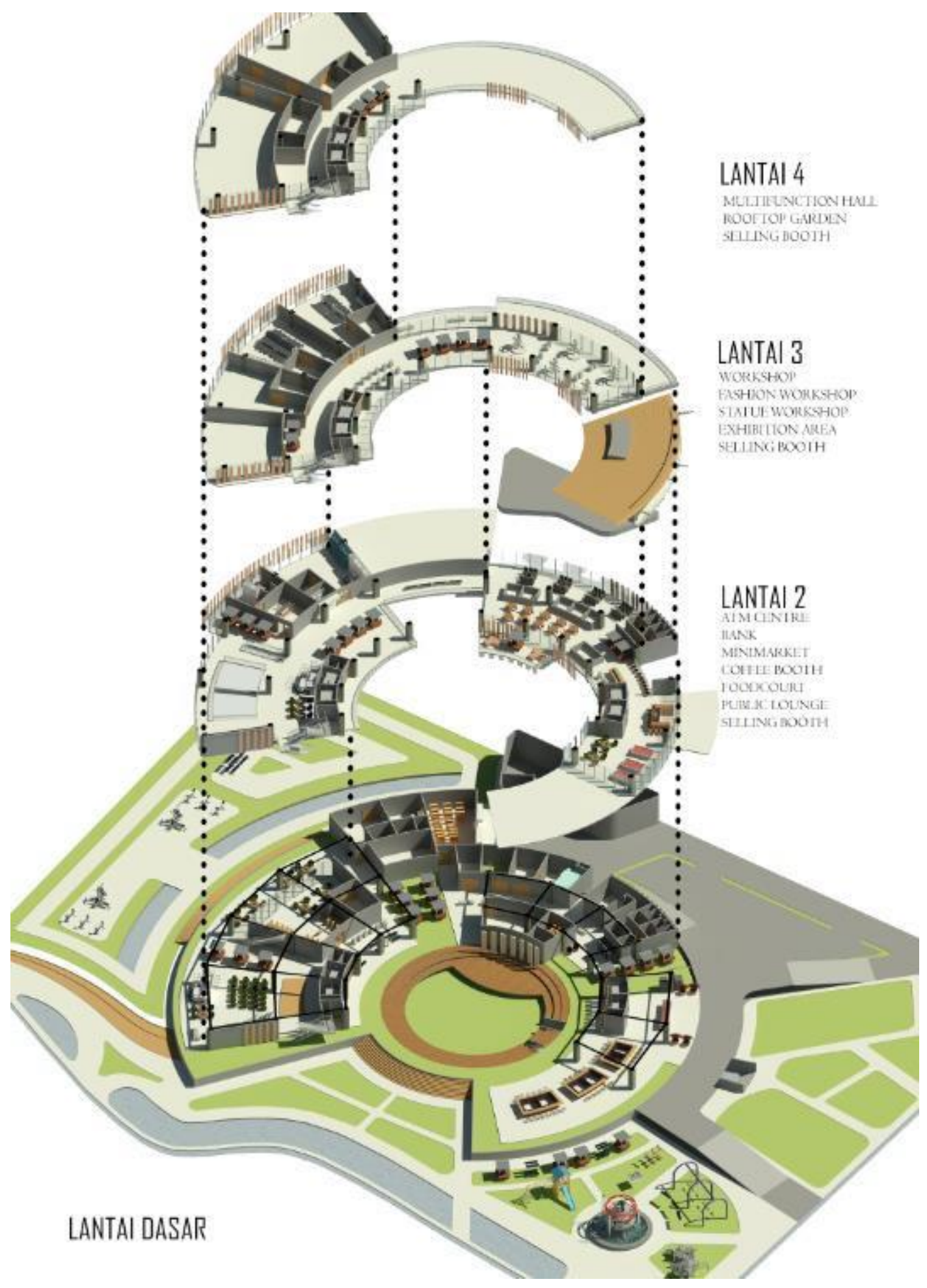

Gambar 4. Denah Exploded

Sumber: Penulis, 2019 


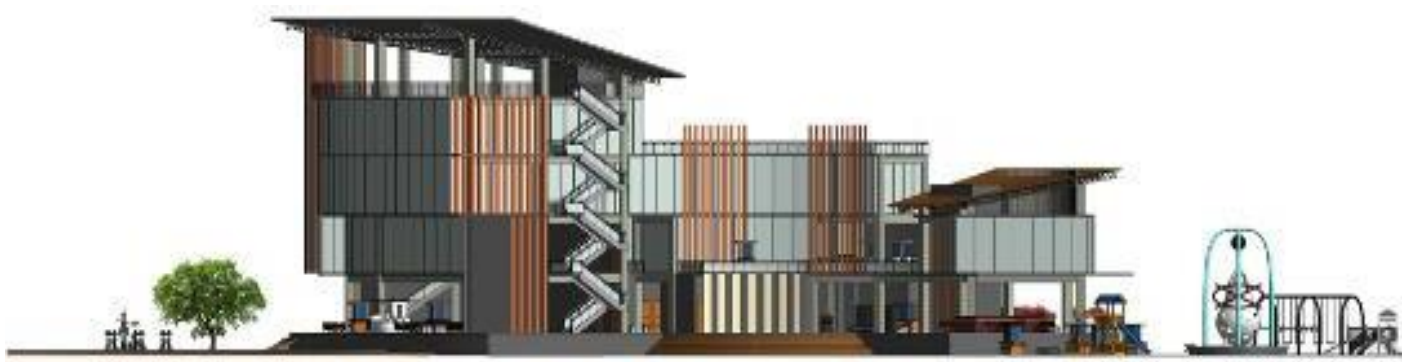

Front View

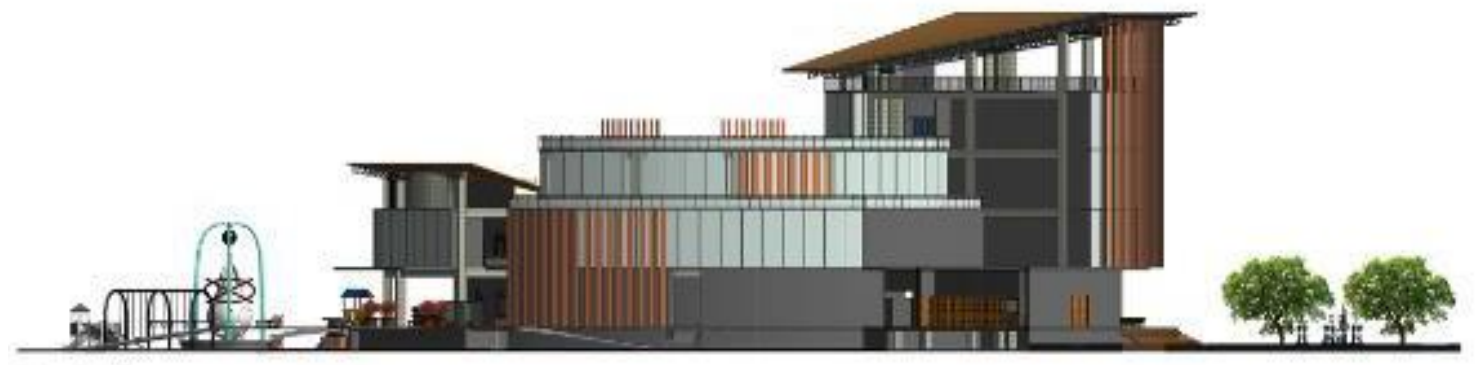

Bock View

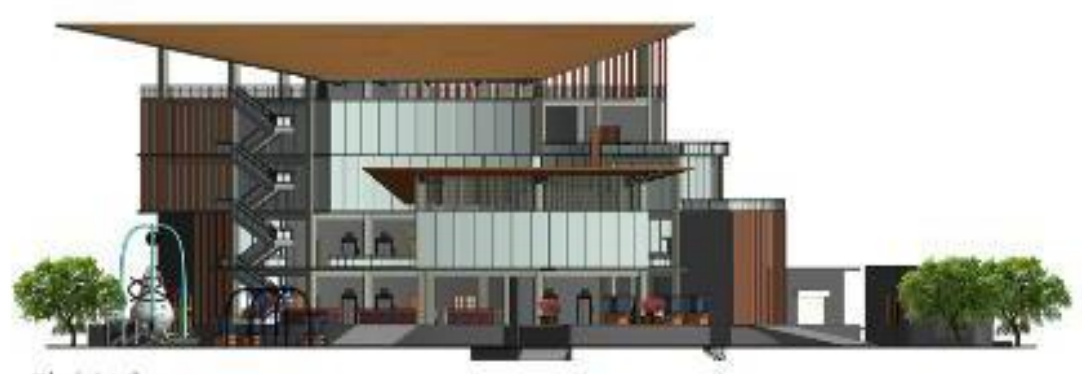

Right View

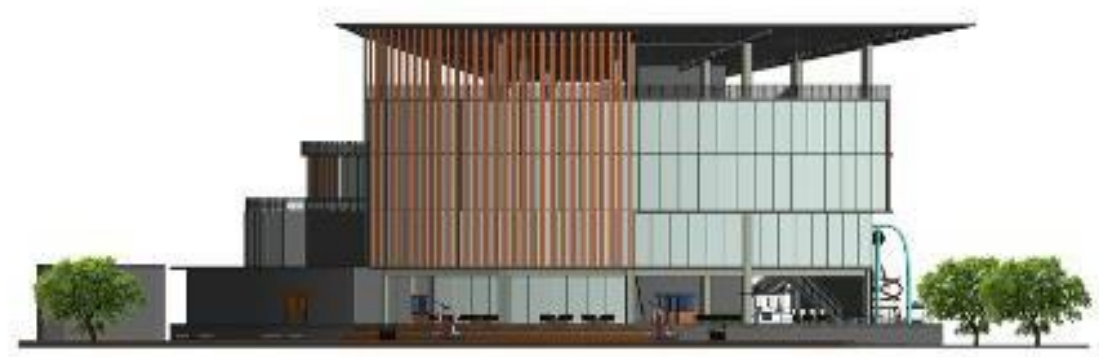

Left View

Gambar 5. Tampak Bangunan

Sumber: Penulis, 2019 

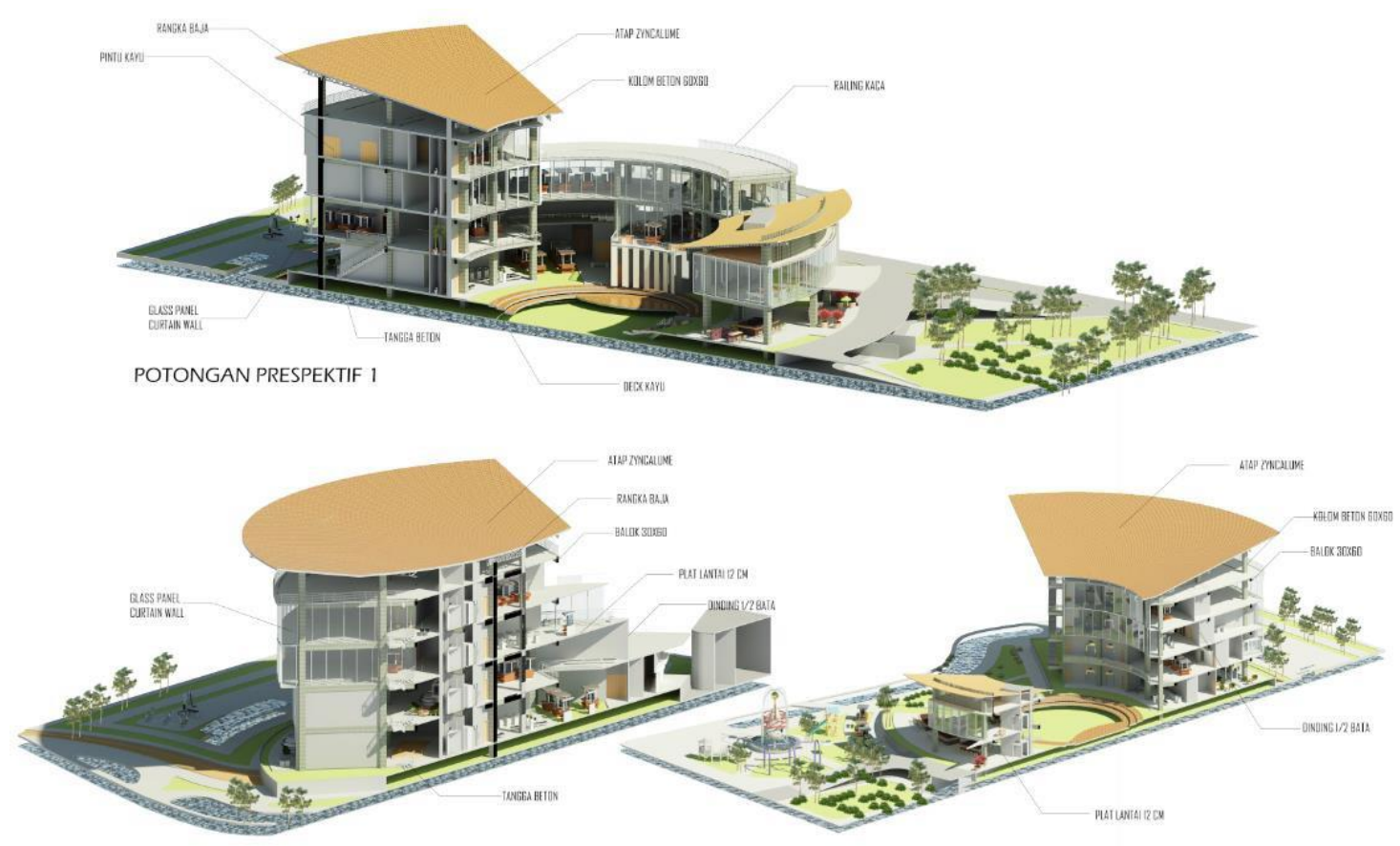

POTONGAN PRESPEKTIF 2

Gambar 6. Potongan Prespektif

Sumber: Penulis, 2019
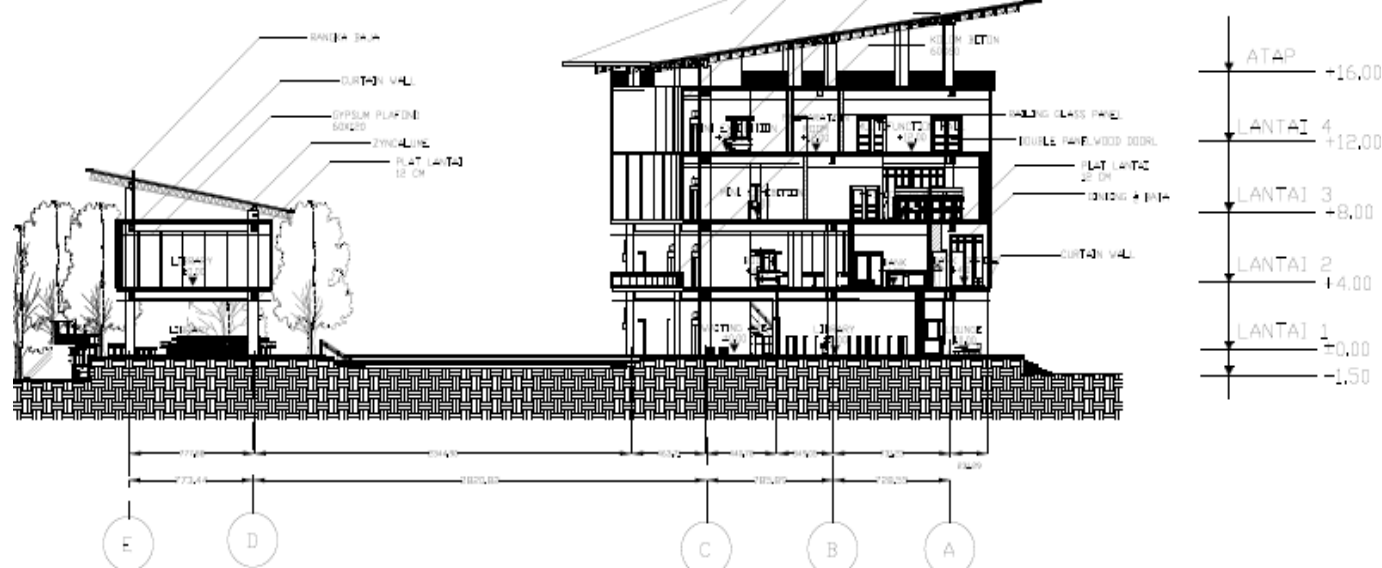

Gambar 7. Potongan

Sumber: Penulis, 2019 


\section{KESIMPULAN DAN SARAN}

Proyek "Pusat Kreatifitas Produk Lokal dan Sarana Interaksi Sosial" memiliki beberapa tujuan , antara lain memberikan edukasi kepada masyarakat, mempersatukan semua kalangan masyarakat, dan yang tak kalah penting adalah menjadi tempat yang menyenangkan bagi masyarakat luas.

Food festival dan tempat untuk bersantai juga disediakan di area ini, untuk memenuhi pelepasan penat bagi mereka yang lelah usai bekerja. Memanfaatkan halte-halte dan rumah di sekitar tapak perancangan untuk menarik orang-orang tersebut.

Tempat ketiga yang akan dibangun akan memiliki sifat yang terbuka, terbuka dari perkembangan zaman, terbuka terhadap segala usia, terbuka terhadap segala jenis kelamin, terbuka terhadap segala status sosial, dan terbuka terhadap segala status ekonomi.

Tempat ketiga yang dibangun juga bersifat fleksibel yang dalam artian perancangan dapat digunakan berbagai macam aktifitas yang berubah-ubah setiap waktunya. Tidak terpaku dengan fungsi ruang yang itu-itu saja, hanya saja diikat dalam satu konteks yaitu produk lokal Indonesia.

\section{BIBLIOGRAFI}

\section{Goffman. 1975. Alt man}

di<http://novenadwirespita10508159.blogspot.com/2011/02/personal-space.html (diakses 6 Agustus 2019)

Hamilton, R. (2003). di https://www.pengertianmenurutparaahli.net/pengertian- komersialdan-nonkomersial/ (diakses 6 Agustus 2019)

Oldenburg, R. (1989). The Great Good Place. Philadepia: Paragon House.

Sommer. 1975. Alt man di http://novenadwirespita10508159.blogspot.com/2011/02/personal-space.html (diakses 6 Agustus 2019)

Winata, S. (2019), The Third place. Materi Kuliah Stupa 8 Prodi SS1 Arsitektur UNTAR. Jakarta

Wirutomo, P. (2012). Sistem Sosial Indonesia. Jakarta: Universitas Indonesia. 60-65 https://id.wikipedia.org/wiki/Sosial ekonomi (diakses 5 Agustus 2019) https://id.wikipedia.org/wiki/Komunitas (diakses 7 Agustus 2019) 